FORAMS 2006

\title{
Foraminiferal and calcareous nannofossil events and the stratigraphic record across the Cretaceous-Paleogene boundary in Campos Basin, southeastern Brazil
}

\author{
Eduardo A. M. Koutsoukos ${ }^{1}$ \& Alexandre de Azevedo Grassi ${ }^{2}$ \\ ${ }^{1}$ PETROBRAS-CENPES, Cidade Universitária, Quadra 7, Ilha do Fundão, 21941-598 \\ Rio de Janeiro, RJ, Brazil \\ ekoutsoukos@gmail.com \\ ${ }^{2}$ PETROBRAS-E\&P/EXP, Centro, Rio de Janeiro, RJ, Brazil
}

An almost complete Cretaceous-Paleogene boundary sequence was recovered in a core section, drilled in the outer shelf (145m of water depth) of the central-south region of Campos Basin, in Rio de Janeiro. The boundary between the uppermost Maastrichtian (Micula prinsii (CC26) nannofossil Zone) and the lowermost Paleocene Danian (Thoracosphaera acme-Zone) is clearly undisturbed, non-bioturbated, and marked by the sharp appearance of a $2.5 \mathrm{~cm}$ thick layer composed of microtektite-like spherules (at 2,166.6m). Iridium concentrations peak to a maximum value of $0.937 \mathrm{ng} / \mathrm{g}$, about 50 times higher the background levels, $4 \mathrm{~cm}$ above the spherule layer. The benthic foraminifera assemblage recovered from the uppermost Maastrichtian section is chiefly composed of Anomalinoides aragonensis, Gavelinella beccariiformis, G. dayi, Gyroidinoides globosus, Nuttallinella coronula, Pullenia bulloides, Ammodiscus cretacea, A. glabratus, Ammoglobigerina globigeriniformis, Arenobulimina sp., Cribrostomoides trinitatensis, Gaudryina pyramidata, Haplophragmoides sp., Hormosinella trinitatensis, Recurvoides sp., Reticulophragmium sp., Reophax globosus, Repmanina charoides corona, Bathysiphon sp. and Rhizammina indivisa, among other typical deep slope dwellers, which suggests a middle bathyal environment. At 2,166.3m there is the first occurrence of Danian planktonic foraminifera (Eoglobigerina edita, E. eobulloides, Guembelitria irregularis, Parvularugoglobigerina eugubina, Woodringina claytonensis and $W$. hornerstownensis), which mark the base of the P $\alpha$ foraminiferal zone. No calcareous nannofossils and foraminifera have been recovered between 2,166.75 and 2,166.55m. Benthic assemblages from the Danian mark a community shift, with the decrease of deep-slope calcareous and agglutinated specimens, and replacement by a typical transitional "Velasco/Midway-type" fauna, such as Anomalinoides alazanensis, A. chiranus, Bolivina midwayensis, Gyroidina bandyi, Gyroidinoides dissimilis, G. girardianus, Hoeglundina sp., 
Osangularia plummerae, O. velascoensis, Clavulinoides plummerae, Arenobulimina sp., and variable numbers of nodosariids and vaginulinids, among others. The Danian foraminiferal assemblage suggests an upper bathyal environment, which is consistent with the record of a sharp sea-level drop across the boundary transition. A similar sea-level fall, in the order of magnitude of 100 to $300 \mathrm{~m}$, was also suggested for the coeval boundary deposits of the Poty section, near Recife, in northeastern Brazil (Koutsoukos, E.A.M., 2005. Applied Stratigraphy, Chapter 7: 147-161, Springer, Dordrecht). 